\title{
Cutaneous Adverse Drug Reactions in Dogs Treated with Antiepileptic Drugs
}

\author{
Tina Koch ${ }^{1}$, Ralf S. Mueller ${ }^{1}$, Britta Dobenecker ${ }^{2}$ and Andrea Fischer ${ }^{1 *}$ \\ ${ }^{1}$ Clinic of Small Animal Medicine, Centre for Clinical Veterinary Medicine, Faculty of Veterinary Medicine, Ludwig Maximilian \\ University Munich, Munich, Germany, ${ }^{2}$ Department of Veterinary Sciences, Ludwig Maximilian University Munich, Munich, \\ Germany
}

\section{OPEN ACCESS}

Edited by:

Luisa De Risio,

Animal Health Trust, UK

Reviewed by:

Rodrigo Gutierrez Quintana,

Glasgow University, UK

Gualtiero Gandini,

University of Bologna, Italy

Karen Dyer Inzana,

Virginia Maryland College of Veterinary Medicine, USA

*Correspondence:

Andrea Fischer

andreafischer@Imu.de

Specialty section: This article was submitted to Veterinary Neurology and Neurosurgery,

a section of the journal Frontiers in Veterinary Science

Received: 15 December 2015 Accepted: 14 March 2016 Published: 14 April 2016

Citation:

Koch T, Mueller RS, Dobenecker B and Fischer A (2016) Cutaneous Adverse Drug Reactions in Dogs Treated with Antiepileptic Drugs.

Front. Vet. Sci. 3:27. doi: 10.3389/fvets.2016.00027
Epilepsy is one of the most common neurologic disorders in dogs and life-long treatment with antiepileptic drugs (AED) is frequently required. Adverse events of AED targeting the skin are only rarely reported in veterinary medicine and the true incidence and spectrum of cutaneous reactions in epileptic dogs remains unknown. In this study, we hypothesized that cutaneous reactions commonly occur in epileptic dogs and are related to AED treatment. A retrospective case review of 185 dogs treated for epilepsy identified $20.0 \%$ with simultaneous appearance of dermatologic signs. In a subsequent prospective case investigation $(n=137)$, we identified newly appearing or distinct worsening of skin lesions following initiation of AED therapy in $10.9 \%$ of dogs treated for epilepsy $(95 \% \mathrm{Cl}$ $6.8-17.7 \%)$. Cutaneous lesions were classified as probably drug-induced in $40.0 \%$ of these cases. Patch testing and intradermal testing were further investigated as potential diagnostic methods to confirm AED hypersensitivity. They were of high specificity but sensitivity and positive predictive value appeared inappropriate to recommend their routine use in clinical practice.

Keywords: epilepsy, phenobarbital, antiepileptic drug, adverse reaction, dermatologic, skin, side effects, patch test

\section{INTRODUCTION}

Anticonvulsant agents are well known to cause adverse drug reactions (ADR) in dogs and cats, and ADRs are a major concern for owners of epileptic $\operatorname{dogs}(1,2)$. However, in those species, effects, which are not immunologically mediated such as polyphagia, polydipsia/polyuria, sedation, and ataxia, or an activation of liver enzymes predominate $(3,4)$. There are only few case reports in the scientific literature regarding immune-mediated hypersensitivity reactions against antiepileptic treatment in animals including blood cell dyscrasias $(5,6)$, idiosyncratic hepatopathy (caused by zonisamide) $(7,8)$, or cutaneous disorders. Superficial necrolytic dermatitis (SND) or more appropriate metabolic epidermal necrosis (MEN) was described to appear after several months to years of phenobarbital (PB) therapy and evidence supported its origin as a hepatocutaneous syndrome $(9,10)$. Dermatologic signs have also been a concern in dogs treated with potassium bromide (panniculitis) $(11,12)$ and zonisamide (erythema multiforme) (13).

Adverse drug reactions are divided into two categories: type 1 ADRs are not immune mediated and attributed to physical or chemical properties of the agent or its metabolites. They are dose dependent and predictable. Type 2 ADRs are immune mediated, idiosyncratic, and occur unpredictably. The 
mechanism of this type of ADR is not completely understood $(14,15)$. It is presumed that all four main types of immune reaction - as defined by Gell and Coombs - play a significant role in drug allergy (14). Manifestations of drug-induced allergic reactions can affect numerous organ systems and lead to liver damage, lymphadenopathy, pneumonia, or hematologic abnormalities, although cutaneous manifestations are most common (16).

In human medicine, antiepileptic drugs (AEDs) are well known to cause cutaneous ADRs in about $3 \%$ of patients treated with an AED (17). These immune-mediated hypersensitivity reactions can range from more frequent mild urticarioid or maculopapular eruptions to severe systemic reactions such as Anticonvulsant Hypersensitivity Syndrome (AHS) (17-19). It is suggested that AHS is triggered by a delayed type immune reaction (Type 4), since drug-specific T-cells appear to play a significant role (20), but several other approaches are discussed to be involved in pathogenesis such as cohesive viral infections with human herpes virus Types 6 and 7 or cytomegalovirus (21, 22). Furthermore, recent investigations indicate that genetic factors predispose to the development of an adverse reaction against AED (23), such as a genetically caused deficiency of detoxifying enzymes, which leads to an accumulation of toxic metabolites $(19,21,22,24)$. Management of ADRs in patients with epilepsy creates specific challenges as any change in AED treatment schedule may increase the risk for seizure recurrence, cluster seizures, or status epilepticus. Patch testing (PT) and intradermal testing (IDT) have been introduced in human medical practice during the last decades in order to predict the probability of an ADR against AED (20, 21).

We hypothesized that cutaneous signs occur more commonly in dogs treated with AEDs than reported in scientific literature. So, the aim of this study was to evaluate the proportion of AEDtreated dogs that developed dermatologic signs and whether these signs are consistent with an ADR. A secondary goal was the investigation of PT and IDT as diagnostic methods.

\section{MATERIALS AND METHODS}

\section{Retrospective Evaluation of Adverse Events}

Medical records of epileptic dogs seen between 01/2007 and $12 / 2012$ were reviewed for documentation of adverse events after initiation of AEDs. Inclusion criteria were a clinical diagnosis of epilepsy (idiopathic or structural) according to published criteria (25), medical treatment with one or more AEDs, and at least one follow-up visit in the clinic at least 2 weeks after drug initiation. Exclusion criteria were presence of or strong suspicion for a systemic disease prior to initiation of AED therapy or simultaneous treatment with other drugs at the time of occurrence of adverse events. In total, 185 dogs were included. All data collected, including blood parameters (hematology, chemistry, liver function test), results of the clinical examination, as well as owner-reported adverse events, were reviewed. The records were particularly screened for appearance of adverse events after initiation of AED therapy such as polydipsia/polyuria, polyphagia, ataxia, sedation, gastrointestinal signs, pancreatitis, hepatopathy, hematologic changes, behavioral changes, respiratory signs, and in particular dermatologic abnormalities. Dermatologic signs were documented by clinicians as part of structurally conducted history and examination. Pancreatitis was assumed if specific canine pancreatic lipase was increased and additionally matching clinical signs and/or matching ultrasonographic findings were present. Hepatopathy was assumed if blood values (decreased albumin, decreased total protein, increased bilirubin, increased ammonia, and increased bile acids in liver function test) and clinical signs indicated it, confirmed by ultrasonographic findings. Each adverse event that occurred after AED initiation was noted, regardless of how long after drug initiation it occurred or whether it resolved again during therapy. Furthermore, we attempted follow-up calls to the owners of the dogs with noted dermatologic signs in order to obtain further information about the causality between occurrence of dermatologic signs and AED therapy.

Then, each case of registered cutaneous signs was classified as a doubtful, possible, probable, or definite ADR, as defined by Naranjo et al. (26) (Table 1). The probability category was assigned from the total score as followed: $<0 / 0=$ doubtful, $1-4=$ possible, $5-8=$ probable, $9 />9=$ definite $(26)$.

\section{Prospective Evaluation of Cutaneous Reactions}

Dogs diagnosed with epilepsy (idiopathic or structural) and treated with AEDs between 01/2013 and 12/2014 were prospectively included and monitored for any new appearance of cutaneous signs after initiation of AED. Whenever feasible, complete dermatologic examination was performed by an ECVD

TABLE 1 | Classification of skin lesions with the Naranjo probability index.

\begin{tabular}{|c|c|c|c|}
\hline Question & Yes & No & Do not know \\
\hline $\begin{array}{l}\text { Are there previous conclusive reports on this } \\
\text { reaction? }\end{array}$ & +1 & -1 & 0 \\
\hline $\begin{array}{l}\text { Did the adverse event appear after the suspected } \\
\text { drug was administered? }\end{array}$ & +2 & -1 & 0 \\
\hline $\begin{array}{l}\text { Did the adverse reaction improve when the drug } \\
\text { was discontinued or a specific antagonist was } \\
\text { administered? }\end{array}$ & +1 & 0 & 0 \\
\hline $\begin{array}{l}\text { Did the adverse reaction reappear when the drug } \\
\text { was readministered? }\end{array}$ & +2 & -1 & 0 \\
\hline $\begin{array}{l}\text { Are there alternative causes (other than the drug) } \\
\text { that could on their own have caused the reaction? }\end{array}$ & -1 & +2 & 0 \\
\hline $\begin{array}{l}\text { Did the reaction reappear when a placebo was } \\
\text { given? }\end{array}$ & -1 & +1 & 0 \\
\hline $\begin{array}{l}\text { Was the drug detected in the blood (or other fluids) } \\
\text { in concentrations known to be toxic? }\end{array}$ & +1 & 0 & 0 \\
\hline $\begin{array}{l}\text { Was the reaction more severe when the dose } \\
\text { was increased or less severe when the dose was } \\
\text { decreased? }\end{array}$ & +1 & 0 & 0 \\
\hline $\begin{array}{l}\text { Did the patient have a similar reaction to the same or } \\
\text { similar drugs in any previous exposure? }\end{array}$ & +1 & 0 & 0 \\
\hline $\begin{array}{l}\text { Was the adverse event confirmed by any objective } \\
\text { evidence? }\end{array}$ & +1 & 0 & 0 \\
\hline
\end{tabular}

Assignment of probability scores: total score $\leq 0=$ doubtful, 1-4 = possible, 5-8 = probable, and $\geq 9=$ definite (26). 
diplomate or resident which routinely included detailed dermatologic history, visual inspection of the lesions, skin scrapings, and cytologic examination in order to describe the appeared lesions as precisely as possible and to exclude other potential causes such as ectoparasites and infections. Inclusion and exclusion criteria were identical to the ones described for the retrospective evaluation. Owners of dogs with dermatologic signs were asked to fill in a standardized questionnaire or alternatively answer a follow-up phone call. Based on this information, cutaneous signs were ranked using the Naranjo probability index as described for the retrospective data.

\section{Evaluation of Patch Test and Intradermal Test Dogs}

Patch test (PT) and IDT were performed in six dogs with a clinical diagnosis of epilepsy, which had developed skin lesions after initiation of PB monotherapy (four dogs) or combination therapy (two dogs).

\section{Control Groups}

Ten laboratory Beagle dogs (two males, eight females, median age 3.8 years; range: $2-4$ years) that had never received any AED and therefore were most likely not sensitized to those allergens and seven dogs with a clinical diagnosis of idiopathic epilepsy (three males, four females, three Border collies, two Labrador Retrievers, one Beagle, and one German shepherd mix; median age: 2.5 years, range: 1.5-9 years) currently treated with $\mathrm{PB}$ monotherapy (2) or combination therapy [two PB/potassium bromide (KBr) and three $\mathrm{PB} /$ levetiracetam (LEV)] without any previous or current dermatologic signs.

In the laboratory Beagle dogs, the PT included PB, potassium bromide, LEV, gabapentin, and zonisamide, and the IDT included $\mathrm{PB}$ and potassium bromide. The privately owned dogs were patch tested for those AEDs, which they currently received or had received previously. $\mathrm{PB}$ and, if the AED treatment included it, potassium bromide were additionally used in the IDT.

\section{Patch Test}

For the patch test, two different concentrations (5 and 10\%) of petrolatum-solved agents were compounded for each AED (Table 2). Tablets were grounded with a tablet grinder to an instant powder, which was solved in petrolatum. Approximately $0.2 \mathrm{cc}$ of the prepared solutions were placed in Finn chambers of $12 \mathrm{~mm}$ diameter. Pure petrolatum was used as negative control. The Finn chambers were placed firmly on the clipped skin on the lateral thorax and carefully fixed by surgical tape as described previously (27). The dogs wore a body suit for $48 \mathrm{~h}$ to prevent

TABLE 2 | Antiepileptic agents unsed in patch tests.

\begin{tabular}{llc}
\hline Active substance & Trade name & Concentration per pill (mg) \\
\hline Phenobarbital & Luminal Vet $^{\circledR}$ & 100 \\
Potassium bromide & Libromide $^{\circledR}$ & 325 \\
Levetiracetam & Keppra $^{\circledR}$ & 100 \\
Gabapentin & Gabapentin, 1A Pharma $^{\circledR}$ & 100 \\
Zonisamide & Zonegran $^{\circledR}$ & 50
\end{tabular}

shifting of the chambers (27-29). After $48 \mathrm{~h}$, the chambers were removed, and the skin reactions were evaluated as described previously (Table 3) (27).

\section{Intradermal Test}

Intradermal testing was performed with $\mathrm{PB}$ and potassium bromide. The corresponding amount of $200 \mathrm{mg}$ effective agent was solved in $2 \mathrm{cc}$ of sterile isotonic saline solution, resulting in a $10 \%$ dilution. To detect the minimum drug dilution not triggering a positive reaction when injected into the skin of a healthy, non-sensitized dog, serial dilutions were prepared (10, 1, 0.1, and $0.01 \%$ ) and injected intradermally into the skin of a healthy laboratory Beagle dog, which had never received any AEDs. Positive reactions were seen with the 10 and $1 \%$ dilution. Consequently, a $0.1 \%$ dilution of both drugs was used subsequently in this study. An area of $20 \mathrm{~cm} \times 15 \mathrm{~cm}$ on the lateral thorax was clipped, and the injection sites were marked by an indelible felt pen. Approximately $0.05 \mathrm{cc}$ of each solution as well as a positive (histamine 1:100,000) and a negative control (sterile isotonic saline solution) were injected intradermally using an insulin syringe $(0.33 \mathrm{~mm} \times 12 \mathrm{~mm})$ as previously described (30). After 15 and $25 \mathrm{~min}$, the skin reaction and diameter of the wheal at the drug injection site were compared to the negative and positive control and graded either negative $(-)$ or positive as,+++ , or +++ , depending on strength of reaction.

Sensitivity, specificity, and positive and negative predictive value of PT and IDT and their 95\% confidence intervals were calculated.

This animal experiment was approved by the government, under the reference 55.2-1-54-2532-4-13. The laboratory dogs were housed according to the prescribed conditions of the German animal protection law. Epileptic dogs were privately owned patients of the clinic. All animal owners signed informed consent prior to study participation.

\section{RESULTS}

\section{Retrospective Evaluation of Adverse Events}

In total, 185 dogs (84.9\% idiopathic epilepsy and $15.1 \%$ structural epilepsy) fulfilled the inclusion criteria. The $52.4 \%$ of the retrospective cases were treated with AED monotherapy [ 93 with $\mathrm{PB}, 3$ with potassium bromide $(\mathrm{KBr})$, and 1 with levetiracetam (LEV)] and $47.6 \%$ with a combination of AED (66 with $\mathrm{PB} / \mathrm{KBr}$, 5 with $\mathrm{PB} / \mathrm{LEV}$, 10 with $\mathrm{PB} / \mathrm{KBr} / \mathrm{LEV}, 3$ with $\mathrm{PB} / \mathrm{KBr} /$ gabepentin, 1 with $\mathrm{PB} / \mathrm{KBr}$ /zonisamide, 1 with $\mathrm{PB} /$ zonisamide, 1 with $\mathrm{PB} /$ $\mathrm{KBr} / \mathrm{LEV} /$ zonisamide/pregabalin, and 1 with $\mathrm{PB} /$ pregabalin/ zonisamie/lacosamide).

\section{TABLE 3 | Evaluation of patch test sites.}

- $\quad$ No visible reaction or irritation

$1+\quad$ Mild erythema

2+ Moderate erythema

3+ Severe erythema

$+\quad \quad$ Erythema and induration or edema (papules)

$++\quad$ Erythema with vesiculation or more severe reactions 
Clinical signs that occurred after initiation of antiepileptic treatment and were considered adverse events are listed in Table 4. Most frequently noted were ataxia (27.1\%), sedation (23.8\%), and polyphagia $(20.5 \%)$, while pancreatitis $(5.4 \%)$ and hepatopathy (2.2\%) were less frequently seen. Neutropenia occurred in six dogs (3.2\%). Cutaneous signs were documented in $20.0 \%$ of the cases, 30 of them diagnosed with idiopathic epilepsy. The dermatologic signs ranged from solely pruritus/alopecia $(n=23)$, skin lesions such as papules, pustules, or erythema $(n=13)$ to severe reactions such as epidermal necrosis $(n=1)$. In total, 26 owners were available for a detailed follow-up phone interview. These owner interrogations revealed that four dogs already had dermatologic signs before AED initiation and two owners could not surely remember whether the dermatologic signs occurred before or after AED therapy. Based on these information and on the clinical records, the Naranjo index (26) was used in order to classify the dermatologic signs as probably related to AED treatment in 2 dogs (5.4\%), possible in 22 dogs (59.5\%), and doubtful in 13 dogs (35.1\%).

\section{Prospective Evaluation of Cutaneous Signs}

Within this study part, 137 dogs (74.5\% idiopathic epilepsy and $25.5 \%$ structural epilepsy) fulfilled the inclusion criteria. Of the 137 dogs, $10.9 \%$ (95\% CI 6.8-17.7\%, 15 dogs) presented with dermatologic signs of varying extent, which appeared after initiation of AED therapy. All of the dogs with dermatologic signs were diagnosed with idiopathic epilepsy except for one (P5) with ambiguous results in neurologic examination, which were not consistent with idiopathic epilepsy. Detailed owner interrogation revealed that three of the dogs already had mild dermatologic signs before onset of seizures which worsened after AED initiation (Table 5). All dogs were treated with PB. Twelve dogs received $\mathrm{PB}$ monotherapy, and three were treated with a $\mathrm{PB}$ combination therapy (PB/LEV, $\mathrm{PB} / \mathrm{KBr}, \mathrm{PB} / \mathrm{LEV} / \mathrm{KBr}$ ). One of the dogs (P14) developed dermatologic signs shortly after initiation of LEV therapy, the others within days to several months after initiation of $\mathrm{PB}$.

Nine dogs (P1, P3-6, P11-13, and P15) underwent complete dermatologic examination performed by a diplomate or resident ECVD, which included detailed dermatologic history and visual inspection of the lesions in all examined dogs as well as cytologic examination $(n=8)$, skin scrapings $(n=4)$, and bacteriological culture $(n=2)$. The remaining six dogs were examined by other clinicians, lacking further dermatologic tests. The cutaneous signs were described as severe with extensive erosions or epidermal necrosis leading to skin detachment in four dogs (P2, P5, P7, and P13). Eight dogs showed moderate signs, most notably papules, pustules, erythema, and crusty lesions, and three dogs showed mainly pruritus and/or alopecia. Particularly affected were the face, especially the periocular region, the mucocutaneous boundaries, the inguinal region, and the limbs (Table 5). Skin scrapings revealed Sarcoptes mites in dog P15. In this dog, antiparasitic therapy led to partial improvement of cutaneous signs. In the other 14 dogs, no other cause for the cutaneous lesions was identified. Skin biopsy was performed in one dog (P13) and indicated presence of erythema multiforme. AED therapy was withdrawn in seven cases (six dogs with PB and one dog with LEV). Cutaneous signs dissolved completely in five dogs within approximately 2 weeks (P2, P5, P11, P13, and P14). In one dog, a clear improvement, although no complete remission, was noticeable (P7), and in another dog (P1), appearance of severe seizures despite concomitant loading with $\mathrm{KBr}$ led to reinstitution of PB therapy after 2 weeks. Treatment for the cutaneous lesions included anti-inflammatory and/or antimicrobial topicals $(n=8)$, antiparasitic agents $(n=6)$, and short-term systemic prednisolone $(n=3)$. Treatment led to improvement of signs in all of the cases. However, this improvement was not complete and only temporary while topical or systemic anti-inflammatory medication was given. Based on the individual patient's history, the examinations and the information obtained by standardized questionnaires, the Naranjo index was applied to classify the cutaneous signs as probably due to AED therapy in $40.0 \%$ (six dogs, all treated with $\mathrm{PB}$ monotherapy), and as possible (eight dogs; $53.3 \%$ ) or doubtful (one dog; 6.7\%) in the remainder (Table 5). As an example, the skin lesions of dog P7 and P13 are depicted in Figures 1A,B and 2A,B. Both dogs had developed dermatologic signs several weeks after initiation of PB therapy and were both classified as probably drug-induced ADR.

\section{Evaluation of Patch Test and Intradermal Test}

Six dogs with cutaneous signs occurring under antiepileptic therapy (four $\mathrm{PB}$ monotherapy, one $\mathrm{PB} / \mathrm{LEV}$, and one $\mathrm{PB} / \mathrm{KBr}$ ) were tested with PT and IDT. Cutaneous signs were classified as probable due to AED therapy in two of these dogs, and as possible due to AEDs in the other four dogs. The clinical details of these

TABLE 4 | Adverse events during AED therapy $(n=185)$.

\begin{tabular}{|c|c|c|c|c|c|c|c|c|c|c|}
\hline & $\begin{array}{c}\text { Polyuria/ } \\
\text { polydypsia }\end{array}$ & Polyphagia & Sedation & Ataxia & $\begin{array}{l}\text { Gastro-intestinal } \\
\text { disorders }\end{array}$ & Pancreatitis & $\begin{array}{c}\text { Changes in } \\
\text { behavior }\end{array}$ & $\begin{array}{c}\text { Respiratory } \\
\text { signs }\end{array}$ & $\begin{array}{l}\text { Dermatol. } \\
\text { signs }\end{array}$ & . Hepatopathy \\
\hline $\mathrm{PB}(n=93)$ & 15 & 19 & 16 & 15 & 4 & 3 & 5 & 0 & 17 & 3 \\
\hline $\operatorname{KBr}(n=3)$ & 0 & 0 & 0 & 1 & 0 & 0 & 0 & 0 & 0 & 0 \\
\hline $\operatorname{LEV}(n=1)$ & 0 & 1 & 0 & 0 & 0 & 0 & 0 & 0 & 1 & 0 \\
\hline $\mathrm{PB}+\operatorname{KBr}(n=66)$ & 15 & 11 & 18 & 24 & 11 & 4 & 8 & 1 & 12 & 1 \\
\hline PB + LEV $(n=5)$ & 1 & 2 & 5 & 3 & 0 & 0 & 0 & 0 & 1 & 0 \\
\hline $\mathrm{PB}+\mathrm{KBr}+\operatorname{LEV}(n=10)$ & 4 & 4 & 4 & 4 & 4 & 3 & 3 & 0 & 4 & 0 \\
\hline Other AED $(n=7)$ & 1 & 1 & 1 & 3 & 2 & 0 & 0 & 1 & 2 & 0 \\
\hline Count & 36 & 38 & 44 & 50 & 21 & 10 & 16 & 2 & 37 & 4 \\
\hline Percentage of all reviewed & 19.5 & 20.5 & 23.8 & 27.0 & 11.4 & 5.4 & 8.6 & 1.1 & 20.0 & 2.2 \\
\hline
\end{tabular}

dogs $(n=185)$ in \% 
TABLE 5 | Prospectively collected cases of skin lesions under antiepileptic treatment.

\begin{tabular}{|c|c|c|c|c|c|c|c|c|c|c|}
\hline No. & Signalment & $\begin{array}{l}\text { Antiepileptic } \\
\text { therapy }\end{array}$ & Adverse events & $\begin{array}{l}\text { Dermatologic } \\
\text { signs prior to } \\
\text { AED therapy }\end{array}$ & $\begin{array}{l}\text { Description of } \\
\text { dermatologic signs after } \\
\text { initiation of AED }\end{array}$ & $\begin{array}{l}\text { Chronological } \\
\text { appearance of } \\
\text { dermatologic } \\
\text { signs }\end{array}$ & $\begin{array}{l}\text { Discontinuation } \\
\text { of AED therapy }\end{array}$ & $\begin{array}{l}\text { Classification } \\
\text { of skin lesions } \\
\text { according to } \\
\text { Naranjo et al. }\end{array}$ & Patch test & $\begin{array}{l}\text { Intra- } \\
\text { dermal } \\
\text { skin test }\end{array}$ \\
\hline P 1 & $\begin{array}{l}\text { Mixed-breed, male, } \\
8 a\end{array}$ & PB & $\begin{array}{l}\text { Dermatologic } \\
\text { signs }\end{array}$ & None & $\begin{array}{l}\text { Severe erosive perianal } \\
\text { inflammation with purulent } \\
\text { secretion }\end{array}$ & $\begin{array}{l}\text { Several months } \\
\text { after initiation of } \\
\text { AED }\end{array}$ & $\begin{array}{l}\text { Yes, but only for } \\
2 \text { weeks, no improving of } \\
\text { skin lesions during that } \\
\text { period }\end{array}$ & Possible & Positive (2+) & Negative \\
\hline P2 & $\begin{array}{l}\text { Saluki, male- } \\
\text { neutered, } 5 \mathrm{a}\end{array}$ & PB & $\begin{array}{l}\text { Dermatologic } \\
\text { signs }\end{array}$ & None & $\begin{array}{l}\text { Erosive-crusty dermatitis, } \\
\text { generalized spread, } \\
\text { especially in the face, at the } \\
\text { testicles and oral mucosa }\end{array}$ & $\begin{array}{l}\text { Several weeks } \\
\text { after initiation of } \\
\text { AED }\end{array}$ & $\begin{array}{l}\text { Yes } \rightarrow \text { complete } \\
\text { remission within } \\
1-2 \text { weeks }\end{array}$ & Probable & Negative & Negative \\
\hline P 3 & $\begin{array}{l}\text { Mixed-breed, male, } \\
4 \mathrm{a}\end{array}$ & $\begin{array}{l}\text { PB later } \\
\text { combination } \\
\text { therapy PB/LEV }\end{array}$ & $\begin{array}{l}\text { Dermatologic } \\
\text { signs }\end{array}$ & None & $\begin{array}{l}\text { Pruritus, crusty lesions } \\
\text { at the hind limbs and } \\
\text { rhinarium }\end{array}$ & $\begin{array}{l}\text { Weeks to months } \\
\text { after PB initiation }\end{array}$ & No & Possible & Negative & $\begin{array}{l}\text { Positive } \\
(++)\end{array}$ \\
\hline P 4 & $\begin{array}{l}\text { Golden Retriever, } \\
\text { female-neutered, } 7 \mathrm{a}\end{array}$ & PB & $\begin{array}{l}\text { Dermatologic } \\
\text { signs }\end{array}$ & None & $\begin{array}{l}\text { Pruritus and alopecia at } \\
\text { the limbs }\end{array}$ & $\begin{array}{l}\text { Several months } \\
\text { after initiation of } \\
\text { AED }\end{array}$ & No & Possible & Negative & Negative \\
\hline P 5 & $\begin{array}{l}\text { Mixed-breed, male, } \\
\text { 3a }\end{array}$ & PB & $\begin{array}{l}\text { Dermatologic } \\
\text { signs }\end{array}$ & None & $\begin{array}{l}\text { Erosive and crusty lesions } \\
\text { perioccular, at the limbs } \\
\text { and foot pads }\end{array}$ & $\begin{array}{l}\text { Several days after } \\
\text { initiation of AED }\end{array}$ & $\begin{array}{l}\text { Immediately after } \\
\text { appearance of } \\
\text { dermatologic } \\
\text { signs } \rightarrow \text { complete } \\
\text { remission within } \\
1-2 \text { weeks }\end{array}$ & Probable & $\begin{array}{l}\text { No definite } \\
\text { result }( \pm)\end{array}$ & Negative \\
\hline P 6 & $\begin{array}{l}\text { Mixed-breed, male, } \\
5 a\end{array}$ & $\begin{array}{l}\text { Combination } \\
\text { therapy } \mathrm{PB} / \mathrm{KBr}\end{array}$ & $\begin{array}{l}\text { Dermatologic } \\
\text { signs }\end{array}$ & None & $\begin{array}{l}\text { Pruritus and alopecia at the } \\
\text { limbs, crusty lesions at the } \\
\text { ears and the inguinal region }\end{array}$ & $\begin{array}{l}\text { Several months } \\
\text { after initiation of } \\
\text { AED }\end{array}$ & No & Possible & Negative & Negative \\
\hline P 7 & $\begin{array}{l}\text { Mixed-breed, male- } \\
\text { neutered, } 8 \mathrm{a}\end{array}$ & PB & $\begin{array}{l}\text { Dermatologic } \\
\text { signs, changes in } \\
\text { behavior }\end{array}$ & None & $\begin{array}{l}\text { Pruritus and crusty lesions } \\
\text { around the eyes, at the } \\
\text { ears, at the armpit area } \\
\text { and breast }\end{array}$ & $\begin{array}{l}\text { Several weeks } \\
\text { after initiation of } \\
\text { AED }\end{array}$ & $\begin{array}{l}\text { Yes, for several weeks, } \\
\text { improving of skin lesions } \\
\text { during that period }\end{array}$ & Probable & - & - \\
\hline P 8 & $\begin{array}{l}\text { Mixed-breed, male- } \\
\text { neutered, 2a }\end{array}$ & PB & $\begin{array}{l}\text { Dermatologic } \\
\text { signs, ataxia }\end{array}$ & None & $\begin{array}{l}\text { Erosive and crusty lesions } \\
\text { in the face and at the limbs }\end{array}$ & $\begin{array}{l}\text { Several weeks } \\
\text { after initiation of } \\
\text { AED }\end{array}$ & No & Probable & - & - \\
\hline P 9 & $\begin{array}{l}\text { Hovawart, male- } \\
\text { neutered, } 2 \mathrm{a}\end{array}$ & PB & $\begin{array}{l}\text { Dermatologic } \\
\text { signs }\end{array}$ & None & $\begin{array}{l}\text { Erosive lesions and } \\
\text { discoloration of oral } \\
\text { mucosa }\end{array}$ & $\begin{array}{l}\text { Weeks to months } \\
\text { after drug initiation }\end{array}$ & No & Possible & - & - \\
\hline P 10 & $\begin{array}{l}\text { Australian } \\
\text { shepherd, male- } \\
\text { neutered, } 8 \text { a }\end{array}$ & PB & $\begin{array}{l}\text { Dermatologic } \\
\text { signs }\end{array}$ & None & $\begin{array}{l}\text { Generalized cornification } \\
\text { of the skin, generalized } \\
\text { spread papules and nodes }\end{array}$ & $\begin{array}{l}\text { Several months } \\
\text { after initiation of } \\
\text { AED }\end{array}$ & No & Possible & - & - \\
\hline
\end{tabular}


TABLE 5 | Continued

\begin{tabular}{|c|c|c|c|c|c|c|c|c|c|c|}
\hline No. & Signalment & $\begin{array}{l}\text { Antiepileptic } \\
\text { therapy }\end{array}$ & Adverse events & $\begin{array}{l}\text { Dermatologic } \\
\text { signs prior to } \\
\text { AED therapy }\end{array}$ & $\begin{array}{l}\text { Description of } \\
\text { dermatologic signs after } \\
\text { initiation of AED }\end{array}$ & $\begin{array}{l}\text { Chronological } \\
\text { appearance of } \\
\text { dermatologic } \\
\text { signs }\end{array}$ & $\begin{array}{l}\text { Discontinuation } \\
\text { of AED therapy }\end{array}$ & $\begin{array}{l}\text { Classification } \\
\text { of skin lesions } \\
\text { according to } \\
\text { Naranjo et al. }\end{array}$ & Patch test & $\begin{array}{l}\text { Intra- } \\
\text { dermal } \\
\text { skin test }\end{array}$ \\
\hline P 11 & $\begin{array}{l}\text { Yorkshire terrier, } \\
\text { male, } 7 \mathrm{a}\end{array}$ & PB & $\begin{array}{l}\text { Dermatologic } \\
\text { signs }\end{array}$ & $\begin{array}{l}\text { Moderate } \\
\text { pruritus because } \\
\text { of flea several } \\
\text { months before }\end{array}$ & $\begin{array}{l}\text { Severe pruritus and skin } \\
\text { rash (pustules, papules, } \\
\text { macule) in the armpit } \\
\text { region and at the flanks }\end{array}$ & $\begin{array}{l}4 \text { days after } \\
\text { initiation of } A E D\end{array}$ & $\begin{array}{l}\text { Yes } \rightarrow \text { complete } \\
\text { remission within } 1 \text { week, } \\
\text { never received PB again }\end{array}$ & Probable & - & - \\
\hline P 12 & $\begin{array}{l}\text { French bulldog, } \\
\text { female-neutered, } 7 \mathrm{a}\end{array}$ & PB & $\begin{array}{l}\text { Dermatologic } \\
\text { signs: PU/PD, } \\
\text { polyphagia }\end{array}$ & $\begin{array}{l}\text { Mild allergic } \\
\text { skin disease } \\
\text { (pruritus) already } \\
\text { before AED } \\
\text { initiation }\end{array}$ & $\begin{array}{l}\text { Aggravation of pruritus } \\
\text { and appearance of crusty } \\
\text { lesions at the rhinarium } \\
\text { and hypotrichous areas } \\
\text { and erythema at the limbs, } \\
\text { perianal inflammation }\end{array}$ & $\begin{array}{l}\text { Weeks to months } \\
\text { after drug initiation }\end{array}$ & No & Doubtful & - & - \\
\hline P 13 & $\begin{array}{l}\text { Australian } \\
\text { shepherd, male, Зa }\end{array}$ & PB & $\begin{array}{l}\text { Dermatologic } \\
\text { signs }\end{array}$ & None & $\begin{array}{l}\text { Generalized spread, } \\
\text { severe erosive, necrolytic } \\
\text { dermatitis, especially at the } \\
\text { mucocutaneous boundary, } \\
\text { foot pads, testicles, } \\
\text { perianal, and in the inguinal } \\
\text { and armpit area }\end{array}$ & $\begin{array}{l}1-2 \text { weeks } \\
\text { after initiation of } \\
\text { phenobarbital } \\
\text { therapy }\end{array}$ & $\begin{array}{l}\text { Immediately after } \\
\text { appearance of } \\
\text { dermatologic } \\
\text { signs - >complete } \\
\text { remission within } \\
1-2 \text { weeks }\end{array}$ & Probable & - & - \\
\hline P 14 & $\begin{array}{l}\text { American bulldog, } \\
\text { male, } 2 a\end{array}$ & $\begin{array}{l}\mathrm{PB} / \mathrm{KBr} \\
\mathrm{LEV} \text { (for several } \\
\text { days) } \\
\text { Later additionally } \\
\text { imepitoin }\end{array}$ & $\begin{array}{l}\text { Dermatologic } \\
\text { signs, } \\
\text { especially under } \\
\text { levetiracetam }\end{array}$ & $\begin{array}{l}\text { Mild pruritus } \\
\text { already before } \\
\text { AED therapy }\end{array}$ & Severe pruritus & $\begin{array}{l}\text { Days after initiation } \\
\text { of LEV therapy }\end{array}$ & $\begin{array}{l}\text { Immediately after } \\
\text { appearance of } \\
\text { dermatologic } \\
\text { signs } \rightarrow \text { complete } \\
\text { remission within several } \\
\text { days }\end{array}$ & Possible & - & - \\
\hline P 15 & $\begin{array}{l}\text { Labrador retriever, } \\
\text { male-neutered, 9a }\end{array}$ & PB & $\begin{array}{l}\text { Dermatologic } \\
\text { signs, polyphagia }\end{array}$ & None & $\begin{array}{l}\text { Generalized spread, crusty, } \\
\text { erosive lesions, alopecic } \\
\text { areas, hypotrichosis at the } \\
\text { limbs }\end{array}$ & $\begin{array}{l}\text { Weeks after drug } \\
\text { initiation }\end{array}$ & $\begin{array}{l}\text { No, but improvement } \\
\text { of signs under } \\
\text { corticosteroids }\end{array}$ & Possible & - & - \\
\hline
\end{tabular}




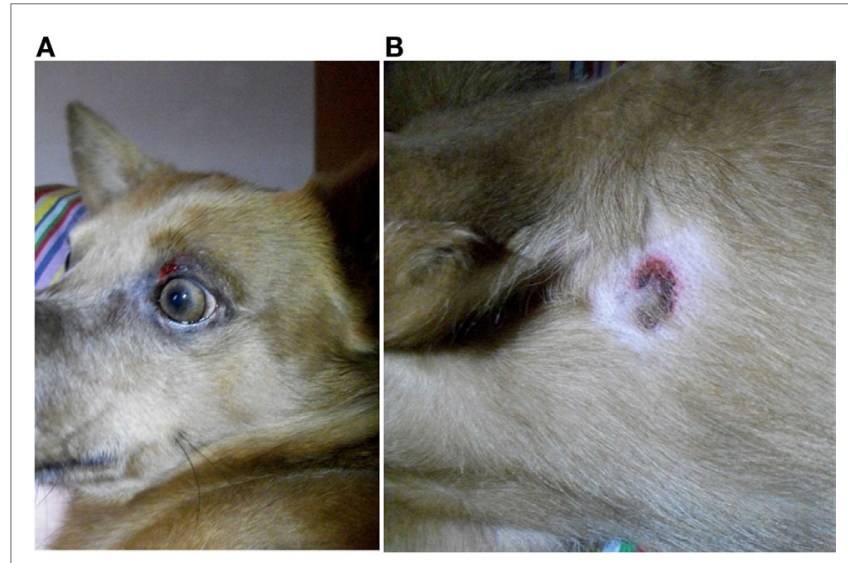

FIGURE 1 | Dog P7 (mixed-breed, male-neutered, 8 years) developed a generalized, erosive-crusty dermatitis, especially in the face (A) and in the axiallry region (B) several weeks after initiation of PB; clear improvement of dermatologic signs after PB withdrawal.
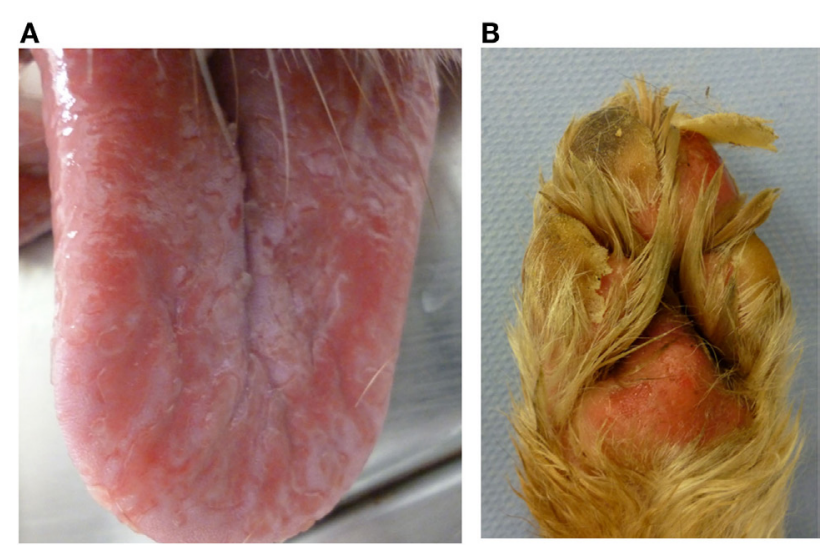

FIGURE 2 | Dog P13 (Australian shepherd, male, 3 years) developed a generalized, severe, erosive necrolytic dermatitis, especially at the oral mucosa (A), at the mucocutaneous junctions and the foot pads (B) 1-2 weeks after PB initiation; additionally affected were the testicles and the perianal, inguinal and axillary areas. After withdrawal of PB therapy, the skin lesions resolved completely within 2 weeks.

patients are listed in Table 5 (P1-P6) and are described below. All six dogs underwent complete dermatologic examination: ectoparasites were not found in any of these dogs but other possible causes for dermatologic signs such as food or environmentally induced atopic dermatitis could not be precluded assuredly. This fact has been regarded in ranking the probability of an adverse event using the Naranjo index.

One of the tested dogs (P1; possible ADR) showed a strong positive reaction in $\mathrm{PT}$ to the $10 \%$ petrolatum-solved $\mathrm{PB}$ (Figures 3A,B). The other patch test sites (negative control and $5 \%$ dilution) as well as intradermal reactions were negative. This $\operatorname{dog}(\mathrm{P} 1,8 \mathrm{a})$ had been treated with PB for several years and developed a severe erosive perianal inflammation a few months after initiation of medical treatment with $\mathrm{PB}$. After the positive $\mathrm{PT}$, the AED therapy was changed to potassium bromide by first
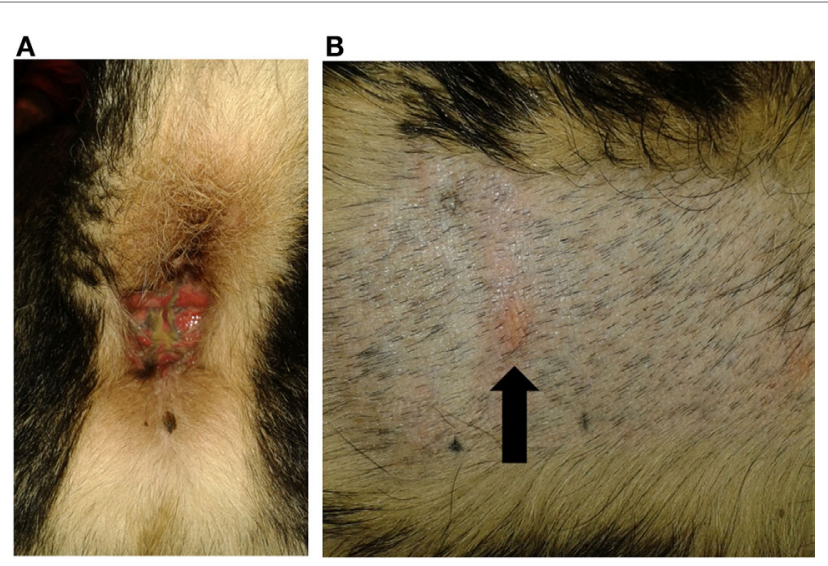

FIGURE 3 | Dog P1 (mixed-breed, male, 8 years) developed a severe erosive perianal inflammation with purulent secretion after PB initiation (A). Patch test revealed a positive reaction to the $10 \%$ phenobarbital (arrowed) (B).

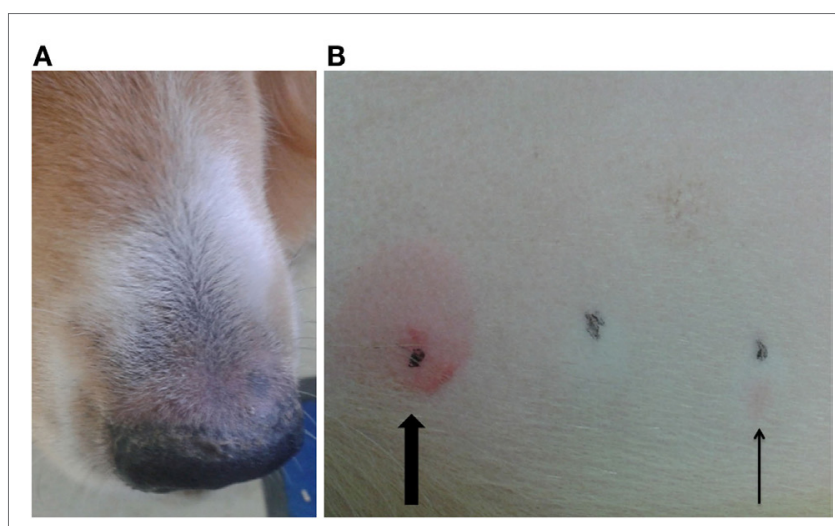

FIGURE 4 | Dog P3 (mixed-breed, male, 4 years) developed pruritus and crusty lesions at the hind limbs and the rhinarium (A). Intradermal test revealed a positive reaction at the phenobarbital injection site (slim arrow), compared to positive control (big arrow) (B).

starting a loading dose of $\mathrm{KBr}(600 \mathrm{mg} / \mathrm{kg}$ per day, over 4 days) and subsequent gradual decrease of PB over a period of 2 weeks. Approximately 2 weeks after cessation of $\mathrm{PB}$, a period of cluster seizures re-occurred, thus $\mathrm{PB}$ therapy was resumed. During the short period off $\mathrm{PB}$, the perianal inflammation did not improve noticeably. It should be noted that this dog already had regular cluster seizures while being treated with $\mathrm{PB}$.

Another $\operatorname{dog}(\mathrm{P} 3$, possible ADR) was positive on IDT for $\mathrm{PB}$, but negative on the patch test (Figures 4A,B). This dog was treated with $\mathrm{PB}$ for 3 years and showed pruritus and crusty lesions at the hind limbs and rhinarium. The cutaneous signs appeared shortly after PB therapy was started. PB therapy was not discontinued in this dog due to the severe cluster seizures seen in that patient.

A third dog (P5) had an ambiguous patch test result against the $10 \%$ PB. This dog received PB only for 1 week. Therapy was then discontinued because of the sudden appearance of severe pruritus 
TABLE 6 | Sensitivity, specificity, positive and negative predictive value of patch testing and intradermal testing for AED hypersensitivity.

\begin{tabular}{lcccc}
\hline & $\begin{array}{c}\text { Sensitivity } \\
(\%)\end{array}$ & $\begin{array}{c}\text { Specificity } \\
\mathbf{( \% )}\end{array}$ & $\begin{array}{c}\text { Positive } \\
\text { predictive } \\
\text { value (\%) }\end{array}$ & $\begin{array}{c}\text { Negative } \\
\text { predictive } \\
\text { value (\%) }\end{array}$ \\
\hline Patch test & 16.7 & 100.0 & 100.0 & 84.4 \\
Intradermal skin test & 16.7 & 100.0 & 100.0 & 84.4 \\
\hline
\end{tabular}

and alopecia at the limbs, crusty lesions periocular, at the ears and the inguinal region and erosive lesions with ulcera at the foot pads. After cessation of PB treatment, the skin lesions resolved completely within 2 weeks. This history supported a cutaneous adverse reaction to $\mathrm{PB}$.

The other three tested dogs (P2, P4, and P6) with skin lesions developed under PB treatment were negative on IDT and PT.

None of the tested healthy laboratory beagle dogs showed a positive reaction on PT or IDT, neither did any of the privateowned dogs of the negative control group (epileptic dogs under $\mathrm{PB}$ treatment without any registered cutaneous signs - currently or previously to AED therapy).

Sensitivity, specificity, and positive and negative predictive value of PT and IDT are listed in Table 6.

\section{DISCUSSION}

This study was initiated based on our own unpublished clinical observations, which suggested simultaneous appearance of skin disease and epilepsy more commonly than previously reported. This prompted further investigations of the prevalence of cutaneous signs and their relationship to AED treatment. Subsequently, we confirmed a surprisingly high prevalence of cutaneous signs with $20 \%$ in the retrospective data analysis, and identified 15 dogs with potentially AED-caused cutaneous signs in the prospective study part. The prevalence in the prospectively evaluated group was $10.9 \%$ (15/137) and exceeded the prevalence of hepatopathy and pancreatitis in this investigation.

Dermatologic examination in our dogs was unable to delineate other etiologies than drug hypersensitivity, such as ectoparasite manifestations or allergies in all but one dog (P15), but not all diagnostic tests were applied to each dog (31). Literature describes a variety of cutaneous signs caused by an $\mathrm{ADR}$, ranging from urticaria and angioedema (immediate drug hypersensitivity), pruritus, or exanthema to severe generalized syndromes such as lupoid/pemphigoid reactions or SND (15). March et al. retrospectively evaluated the appearance of SND/MEN with chronic $\mathrm{PB}$ administration in dogs (9). The two main differences between the results of this study and our results were the duration of AED treatment before onset of skin lesions (a median of 7 years in March's study and weeks to months in our cases) and the severity of skin lesions (more severe and potentially life-threatening SND/MEN in March's study versus predominantly mild to moderate cutaneous signs in our study). March et al. focused on a PB-induced hepatopathy, while we evaluated any reaction to the drug which may be the explanation for this difference.

In order to further highlight the relationship between AED treatment and appearance of cutaneous signs the ADR probability scale of Naranjo et al. (26), a classification system validated in human medicine
$(32,33)$, was applied. This scale estimates the likelihood of an ADR based on a number of criteria (Table 1). It is particularly helpful when proof of a drug reaction cannot be achieved under clinical circumstances with a drug challenge for ethical reasons, and also accounts for missing information on particular details, e.g., whether cutaneous signs were present prior to AED treatment. The individual patient history was reviewed with regard to the chronological relationship between initiation of drug treatment and appearance of dermatologic signs, the precise localization and appearance of skin lesions and whether signs improved after withdrawal of AED whenever feasible. Based on this evaluation, 2 of the 37 retrospective cases and 6 of the 15 prospective cases were classified as probably suffering from anticonvulsant drug hypersensitivity.

Another explanation for the high prevalence of dermatologic signs in epileptic dogs may be that there are common immunologic mechanisms underlying both the skin disease and the epilepsy. Several different facts support this hypothesis: food allergies or asthma might increase the risk of developing seizure disorders in humans and animals $(34,35)$. Mouse models show inflammatory pathways involved in allergic diseases that may also be activated in the brain and may cause epilepsy (36). Dietary supplementation with either $\omega 3$ fatty acids or medium chain triglycerides are used to improve seizure control in individuals with refractory epilepsy (37-41) and are also successfully administered to dogs with atopic dermatitis $(42,43)$. Thus, there may be a link between allergic diseases and epilepsy leading to cutaneous signs in epileptic dogs independent of antiepileptic therapy. Investigations indicate that in humans, genetic factors predispose for developing an adverse reaction against AED (23). In contrast, in this study no breed predisposition for developing adverse events could be determined.

Secondary goal of our study was to evaluate PT and IDT as potential diagnostic methods in suspected ADRs against AEDs in dogs. In human, medicine PT is already frequently used to confirm AHS (44). In previous studies, the positive predictive value was much higher than the negative predictive value and the validity of the PT varied between the different AEDs (highest for carbamazepine, lowest for PB) (28). In contrast, in veterinary medicine, there are only few reports about the use of skin tests as diagnostic tools for ADRs. In 2008, Murayama described PT to identify an allergic reaction to ingredients of a shampoo in a miniature schnauzer $(20,45)$. Apart from this, PT proved useful as an aid to choose the ingredients of an elimination diet in dogs with adverse food reaction (27), and IDT is widely used to identify offending environmental allergens in dogs with atopic dermatitis (30). Those established methods were used as guidance to develop the skin tests in our study. Both tests showed a high negative predictive value, none of the healthy controls and none of the epileptic dogs under PB therapy without dermatologic signs showed a positive reaction in either PT or IDT. In the positive control group $(n=6)$, one of the tested dogs was positive on patch test, and one of the dogs showed a positive reaction on IDT. The contradictory results of PT and IDT in these two dogs might be due to different underlying immune mechanisms. An IDT evaluated shortly after injection as in this study is more sensitive for immediate hypersensitivity reactions, in contrast PT is more sensitive for delayed-type hypersensitivity 
reactions (46-48). A late judged IDT (evaluation of skin reaction after hours or days) might have revealed other results but was not feasible in this study. Thus, PT and IDT in the present form were insufficient to confirm suspected AED hypersensitivity, which might indicate that other mechanisms than drug hypersensitivity were involved, or that a modification of the skin test protocol with higher drug concentrations or different application methods is needed.

This study also provided insights into occurrence of adverse events of AEDs previously reported $(1,2,49)$ in comparison to the appearance of dermatologic signs. Ataxia and sedation occurred in approximately a quarter of the patients. These are known side effects of AEDs $(2,3)$, occur most common during the first weeks of therapy and tend to improve (3). Hepatopathy, pancreatitis, and blood dyscrasias are of major concern in literature $(5,6,50-52)$, but occurred less frequently than dermatologic signs in this study population (hepatopathy in $1 / 50$, pancreatitis in $1 / 20$, neutropenia in $1 / 30$ ). This should be considered when educating clients about side effects of AED therapy.

Limitations of the study are certainly that we did not use other approaches to confirm AED hypersensitivity. A major limitation of this study is that not all of the dogs were examined by a veterinary dermatologist and that further dermatologic examinations were not performed on each dog. Although cutaneous signs in a proportion of dogs were also suggestive of MEN, histopathologic confirmation was only obtained in one dog and sonography of the liver to show typical sonographic changes of MEN was not performed because of lacking owner-acquiescence. Also none

\section{REFERENCES}

1. Chang Y, Mellor DJ, Anderson TJ. Idiopathic epilepsy in dogs: owners' perspectives on management with phenobarbitone and/ or potassium bromide. J Small Anim Pract (2006) 47:574-81. doi:10.1111/j.1748-5827.2006.00203.x

2. Dewey CW. Anticonvulsant therapy in dogs and cats. Vet Clin North Am Small Anim Pract (2006) 36:1107-1127, vii. doi:10.1016/j.cvsm.2006.05.005

3. Boothe DM, Dewey C, Carpenter DM. Comparison of phenobarbital with bromide as a first-choice antiepileptic drug for treatment of epilepsy in dogs. J Am Vet Med Assoc (2012) 240:1073-83. doi:10.2460/ javma.240.9.1073

4. Fischer A, Jurina K, Potschka H, Rentmeister K, Tipold A, Volk HA, et al. Die idiopathische Epilepsie des Hundes. Stuttgart: Enke Verlag (2013).

5. Weiss DJ. Drug-associated blood cell dyscrasias. Compend Contin Educ Vet (2012) 34:E1-8.

6. Bersan E, Volk HA, Ros C, De Risio L. Phenobarbitone-induced haematological abnormalities in idiopathic epileptic dogs: prevalence, risk factors, clinical presentation and outcome. Vet Rec (2014) 175:247. doi:10.1136/ vr. 102158

7. Miller ML, Center SA, Randolph JF, Lepherd ML, Cautela MA, Dewey CW. Apparent acute idiosyncratic hepatic necrosis associated with zonisamide administration in a dog. J Vet Intern Med (2011) 25:1156-60. doi:10.1111/j.1939-1676.2011.00783.x

8. Schwartz M, Munana KR, Olby NJ. Possible drug-induced hepatopathy in a dog receiving zonisamide monotherapy for treatment of cryptogenic epilepsy. J Vet Med Sci (2011) 73:1505-8. doi:10.1292/jvms.11-0164

9. March PA, Hillier A, Weisbrode SE, Mattoon JS, Johnson SE, DiBartola SP, et al. Superficial necrolytic dermatitis in 11 dogs with a history of phenobarbital administration (1995-2002). J Vet Intern Med (2004) 18:65-74. doi:10.11 11/j.1939-1676.2004.tb00137.x

10. Bevier DE, Miller MA, Rohleder JJ, Wozniak AD. Pathology in practice. Superficial necrolytic dermatitis. J Am Vet Med Assoc (2010) 237:365-7. doi:10.2460/javma.237.4.365 of the dogs, in whom skin reactions disappeared after cessation of anticonvulsants, underwent a second challenge with the drug for ethical reasons, although this would have confirmed AED hypersensitivity reaction more reliably.

In summary, based on the results of this study, dermatologic signs appear realtively frequently in epileptic dogs treated with AED. The pathomechanism of those cutaneous signs needs to be further investigated. Moreover, patch testing and intradermal testing should be evaluated for the diagnosis of a suspected drug hypersensitivity in a larger number of dogs on AED with cutaneous signs. Changes to the protocol of those tests may increase the positive predictability while maintaining the safety of those tests.

\section{AUTHOR CONTRIBUTIONS}

TK: designed the experiments, conducted the experiments, and wrote first draft of the paper. RM: designed the experiments and provided corrections and feedback on first drafts of paper. BD: assisted in the experimental part on research dogs. AF: designed the experiments, and provided detailed corrections and feedback on interpretations of results and first drafts of paper.

\section{SUPPLEMENTARY MATERIAL}

The Supplementary Material for this article can be found online at http://journal.frontiersin.org/article/10.3389/fvets.2016.00027

11. Diener W, Sorni M, Ruile S, Rude P, Kruse R, Becker E, et al. Panniculitis due to potassium bromide. Brain Dev (1998) 20:83-7. doi:10.1016/ S0387-7604(97)00110-1

12. Boynosky NA, Stokking LB. Potassium bromide-associated panniculitis. J Small Anim Pract (2014) 55:640-2. doi:10.1111/jsap.12129

13. Ackermann AL, Frank LA, McEntee MF, May ER. Erythema multiforme associated with zonisamide in a dog. Vet Dermatol (2015) 26:391-e389. doi:10.1111/vde.12237

14. Schnyder B, Pichler WJ. Mechanisms of drug-induced allergy. Mayo Clin Proc (2009) 84:268-72. doi:10.1016/S0025-6196(11)61145-2

15. Voie KL, Campbell KL, Lavergne SN. Drug hypersensitivity reactions targeting the skin in dogs and cats. J Vet Intern Med (2012) 26:863-74. doi:10.1111/j.1939-1676.2012.00927.x

16. Khan DA, Solensky R. Drug allergy. J Allergy Clin Immunol (2010) 125(2 Suppl 2):126-37. doi:10.1016/j.jaci.2009.10.028

17. Blaszczyk B, Lason W, Czuczwar SJ. Antiepileptic drugs and adverse skin reactions: an update. Pharmacol Rep (2015) 67:426-34. doi:10.1016/j. pharep.2014.11.009

18. Bavdekar SB, Muranjan MN, Gogtay NJ, Kantharia V, Kshirsagar NA. Anticonvulsant hypersensitivity syndrome: lymphocyte toxicity assay for the confirmation of diagnosis and risk assessment. Ann Pharmacother (2004) 38:1648-50. doi:10.1345/aph.1E042

19. Criado PR, Avancini J, Santi CG, Medrado AT, Rodrigues CE, de Carvalho JF Drug reaction with eosinophilia and systemic symptoms (DRESS): a complex interaction of drugs, viruses and the immune system. Isr Med Assoc J (2012) 14:577-82.

20. Santiago F, Concalo M, Viera R, Coelho S, Figueiredo A. Epicutaneous patch testing in drug hypersensitivity syndrome (DRESS). Contact Dermatitis (2010) 62:47-53. doi:10.1111/j.1600-0536.2009.01659.x

21. Gogtay NJ, Bavdekar SB, Kshirsagar NA. Anticonvulsant hypersensitivity syndrome, a review. Expert Opin Drug Saf (2005) 4:571-81. doi:10.1517/14740338.4.3.571

22. Inadomi T. Drug rash with eosinophilia and systemic symptoms (DRESS): changing carbamazepine to phenobarbital controlled epilepsy without 
the recurrence of DRESS. Eur J Dermatol (2010) 20:220-2. doi:10.1684/ ejd.2010.0887

23. Franciotta D, Kwan P, Perucca E. Genetic basis for idiosyncratic reactions to antiepileptic drugs. Curr Opin Neurol (2009) 22:144-9. doi:10.1097/ WCO.0b013e328328f276

24. Mansur AT, Yasar SP, Göktay F. Anticonvulsant hypersensitivity syndrome: clinical and laboratory features. Int J Dermatol (2008) 47:1184-9. doi:10.1111/j.1365-4632.2008.03827.x

25. Berendt M, Farquhar RG, Mandigers PJ, Pakozdy A, Bhatti SF, De Risio L, et al. International veterinary epilepsy task force consensus report on epilepsy definition, classification and terminology in companion animals. BMC Vet Res (2015) 11:182. doi:10.1186/s12917-015-0461-2

26. Naranjo CA, Busto U, Sellers EM, Sandor P, Ruiz I, Roberts EA, et al. A method for estimating the probability of adverse drug reactions. Clin Pharmacol Ther (1981) 30:239-45. doi:10.1038/clpt.1981.154

27. Bethlehem S, Bexleyb J, Mueller RS. Patch testing and allergen-specific serum IgE and IgG antibodies in thediagnosis of canine adverse food reactions. Vet Immunol Immunopathol (2012) 145:582-9. doi:10.1016/j.vetimm.2012.01.003

28. Elzagallaai AA, Knowles SR, Rieder MJ, Bend JR, Shear NH, Koren G. Patch testing for the diagnosis of anticonvulsant hypersensitivity syndrome: a systematic review. Drug Saf (2009) 32:391-408. doi:10.2165/00002018-200932050-00003

29. Friedmann PS, Ardern-Jones M. Patch testing in drug allergy. Curr Opin Allergy Clin Immunol (2010) 10:291-6. doi:10.1097/ACI.0b013e32833aa54d

30. Hillier A, DeBoer DJ. The ACVD task force on canine atopic dermatitis (XVII): intradermal testing. Vet Immunol Immunopathol (2001) 81:289-304. doi:10.1016/S0165-2427(01)00296-3

31. Hill PB, Lo A, Eden CA, Huntley S, Morey V, Ramsey S, et al. Survey of the prevalence, diagnosis and treatment of dermatological conditions in small animals in general practice. Vet Rec (2006) 158:533-9. doi:10.1136/vr.158.16.533

32. Liang R, Borgundvaag B, McIntyre M, Thwaites C, Ragan K, Wyllie A. Evaluation of the reproducibility of the Naranjo Adverse Drug Reaction Probability Scale score in published case reports. Pharmacotherapy (2014) 34:1159-66. doi:10.1002/phar.1496

33. Khan A, Adil MS, Nematullah K, Ihtisham S, Aamer K, Aamir S. Causality assessment of adverse drug reaction in Pulmonology Department of a Tertiary CareHospital.J BasicClin Pharm(2015)6:84-8. doi:10.4103/0976-0105.160744

34. Larsen JA, Owens TJ, Fascetti AJ. Nutritional management of idiopathic epilepsy in dogs. JAm Vet Med Assoc (2014) 245:504-8. doi:10.2460/ javma.245.5.504

35. Silverberg JI, Joks R, Durkin HG. Allergic disease is associated with epilepsy in childhood: a US population-based study. Allergy (2014) 69:95-103. doi:10.1111/all.12319

36. Silverberg J, Ginsburg D, Orman R, Amassian V, Durkin HG, Stewart M. Lymphocyte infiltration of neocortex and hippocampus after a single brief seizure in mice. Brain Behav Immun (2010) 24:263-72. doi:10.1016/j. bbi.2009.10.006

37. Scorza FA, Cavalheiro EA, Arida RM, Terra VC, Scorza CA, Ribeiro MO, et al. Positive impact of omega-3 fatty acid supplementation in a dog with drug-resistant epilepsy: a case study. Epilepsy Behav (2009) 15:527-8. doi:10.1016/j. yebeh.2009.05.013

38. Borges K, Sonnewald U. Triheptanoin - a medium chain triglyceride with odd chain fatty acids: a new anaplerotic anticonvulsant treatment? Epilepsy Res (2012) 100:239-44. doi:10.1016/j.eplepsyres.2011.05.023

39. DeGiorgio CM, Miller PR, Harper R, Gornbein J, Schrader L, Soss J, et al. Fish oil (n-3 fatty acids) in drug resistant epilepsy: a randomised placebo-controlled crossover study. J Neurol Neurosurg Psychiatry (2015) 86:65-70. doi:10.1136/ jnnp-2014-307749

40. Law TH, Davies ES, Pan Y, Zanghi B, Want E, Volk HA. A randomised trial of a medium-chain TAG diet as treatment for dogs with idiopathic epilepsy. $\mathrm{Br}$ J Nutr (2015) 114:1438-47. doi:10.1017/S000711451500313X

41. Reda DM, Abd-El-Fatah NK, Omar Tel S, Darwish OA. Fish oil intake and seizure control in children with medically resistant epilepsy. N Am J Med Sci (2015) 7:317-21. doi:10.4103/1947-2714.161248

42. Mueller RS, Fieseler KV, Fettman MJ, Zabel S, Rosychuk RA, Ogilvie GK, et al. Effect of omega-3 fatty acids on canine atopic dermatitis. J Small Anim Pract (2004) 45:293-7. doi:10.1111/j.1748-5827.2004.tb00238.x

43. Schumann J, Basiouni S, Guck T, Fuhrmann H. Treating canine atopic dermatitis with unsaturated fatty acids: the role of mast cells and potential mechanisms of action. J Anim Physiol Anim Nutr (Berl) (2014) 98:1013-20. doi:10.1111/jpn.12181

44. Aquino MR, Sher J, Fonacier L. Patch testing for drugs. Dermatitis (2013) 24:205-14. doi:10.1097/DER.0b013e3182a0d38a

45. Murayama N, Midorikawa K, Nagata M. A case of superficial suppurative necrolytic dermatitis of miniature schnauzers with identification of a causative agent using patch testing. Vet Dermatol (2008) 19:395-9. doi:10.1111/j.1365-3164.2008.00708.x

46. Romano A, Viola M, Gaeta F, Rumi G, Maggioletti M. Patch testing in non-immediate drug eruptions. Allergy Asthma Clin Immunol (2008) 4:66-74. doi:10.1186/1710-1492-4-2-66

47. Rueff F, Bergmann KC, Brockow K, Fuchs T, Grubl A, Jung K, et al. [Skin tests for diagnostics of allergic immediate-type reactions. Guideline of the German Society for Allergology and Clinical Immunology]. Pneumologie (2011) 65:484-95. doi:10.1055/s-0030-1256476

48. Rive CM, Bourke J, Phillips EJ. Testing for drug hypersensitivity syndromes. Clin Biochem Rev (2013) 34:15-38.

49. Muller PB, Taboada J, Hosgood G, Partington BP, VanSteenhouse JL, Taylor HW, et al. Effects of long-term phenobarbital treatment on the liver in dogs. $J$ Vet Intern Med (2000) 14:165-71. doi:10.1111/j.1939-1676.2000.tb02230.x

50. Gaskill CL, Cribb AE. Pancreatitis associated with potassium bromide/phenobarbital combination therapy in epileptic dogs. Can Vet J (2000) 41:555-8.

51. Kluger EK, Malik R, Ilkin WJ, Snow D, Sullivan DR, Govendir M. Serum triglyceride concentration in dogs with epilepsy treated with phenobarbital or with phenobarbital and bromide. J Am Vet Med Assoc (2008) 233:1270-7. doi:10.2460/javma.233.8.1270

52. Tipold A, Keefe TJ, Loscher W, Rundfeldt C, de Vries F. Clinical efficacy and safety of imepitoin in comparison with phenobarbital for the control of idiopathic epilepsy in dogs. J Vet Pharmacol Ther (2015) 38:160-8. doi:10.1111/ jvp. 12151

Conflict of Interest Statement: The authors declare that the research was conducted in the absence of any commercial or financial relationships that could be construed as a potential conflict of interest.

Copyright $\odot 2016$ Koch, Mueller, Dobenecker and Fischer. This is an open-access article distributed under the terms of the Creative Commons Attribution License (CC BY). The use, distribution or reproduction in other forums is permitted, provided the original author(s) or licensor are credited and that the original publication in this journal is cited, in accordance with accepted academic practice. No use, distribution or reproduction is permitted which does not comply with these terms. 